of the resistant organisms found in human populations that have never been treated with antibiotics. ${ }^{6} 10$ Visitors may have brought R-factor-carrying bacteria from localities where antibiotic use was widespread.

The long-term effect of antibiotics on the $E$ coli flora of the population as a whole seems therefore to be insidious rather than dramatic, unlike the case with Salmonella species. ${ }^{324}$ But its implications are none the less important. Nor should one be lulled into a sense of false security by the apparent inferiority of some R-factor-carrying strains at surviving in the gut when compared with the survival of their sensitive counterparts. The relative rarity of $\mathrm{R}$ factors in those strains of $E$ coli notably effective at colonizing the gut of man in the absence of selection pressure means that the potential reservoir in the human population is not yet as full as it might be. But this is no excuse for using antibiotics with anything but scrupulous care.

This work was supported by grants from the Medical and Agricultural Research Councils.

\section{References}

1 Smith, D. H., and Armour, S. E., Lancet, 1966, 2, 15.

2 Lebek, G., Pathologia et Microbiologia, 1967, 30, 1015.

3 Anderson, E. S., Annual Review of Microbiology, 1968, 22, 131.

4 Grüneberg, R. N., Leigh, D. A., and Brumfitt, W., in Urinary Tract Infection, ed. W. Brumfitt and F. O'Grady, p. 68. London, Oxford University Press, 1968.
5 Joint Committee on the Use of Antibiotics in Animal Husbandry and Veterinary Medicine, Report, Cmnd. 4190. London, H.M.S.O., 1969. (Swann Report.)

6 Datta, N., British Medical fournal, 1969, 2, 407.

7 Lincoln, K., Lidin-Janson, G., and Winberg, J., British Medical Fournal, $1970,3,305$.

8 Walton, J. R., Annals of the New York Academy of Sciences, 1971, 182, 358.

9 Jonsson, M., Scandinavian Fournal of Infectious Diseases, 1972, Suppl. No. 5.

${ }^{10}$ Richmond, M. H., fournal of Applied Bacteriology, 1972, 35, 155.

11 Jukes, T. H., Advances in Applied Microbiology, 1973, 16, 1.

12 Richmond, M. H., in Microbiology, 1974, ed. F. Schlessinger, p. 27. Washington, American Society for Microbiology, 1974.

${ }^{13}$ Sompolinsky, D., Yaron, V., and Alkan, W. J., American fournal of. Proctology, 1967, 18, 471.

14 Smith, H. W., New Zealand Veterinary fournal, 1967, 15, 153.

15 Maré, I. J., Nature, 1968, 220, 1046.

16 Gardner, P., et al., Lancet, 1969, 2, 774.

17 Anderson, J. D., fournal of Medical Microbiology, 1974, 7, 85.

${ }^{18}$ Hartley, C. M., Linton, K. B., and Richmond, M. H., Fournal of Medical Microbiology. In press.

19 Hartley, C. M., et al., Antimicrobial Agents and Chemotherapy, 1975. In press.

${ }^{20}$ Wiedemann, B., and Knothe, H., Archiv für Hygiene and Bakteriologie, $1969,153,342$.

21 Benveniste, R., and Davies, J., Annual Review of Biochemistry, 1973, 42, 471.

22 Ewing, W. H., and Davis, B. R., The O-antigen Groups of E. coli Cultures from Different Sources, p. 1. Atlanta, U.S.A., CDC Publications, 1961. ${ }^{23}$ Guinée, P. A. M., Zentralblatt für Bakteriologie, 1963, Abt. I, Originale, $188,201$.

24 Anderson, E. S., British Medical fournal, 1972, 3, 329.

\title{
Intravenous diazoxide in treatment of hypertension associated with recent myocardial infarction
}

\author{
K P O'BRIEN, R R GRIGOR, P M TAYLOR
}

British Medical fournal, 1975, 4, 74-77

\begin{abstract}
Summary
Twenty patients with blood pressure over $180 / 110 \mathrm{~mm} \mathrm{Hg}$ one hour after admission to a coronary care unit with recent acute myocardial infarction were given intravenous diazoxide in a bolus of $300 \mathrm{mg}$. The average blood pressure before diazoxide was $194 / 122 \mathrm{~mm}$ Hg. Blood pressure fell considerably in all patients, though six patients required two injections. The average fall was $58 \mathrm{~mm} \mathrm{Hg}$ systolic and $40 \mathrm{~mm} \mathrm{Hg}$ diastolic. No patient became severely hypotensive. The heart rate increased by an average of 10 beats/min. In nine patients the electrocardiographic changes immediately after the administration of diazoxide suggested an increase in myocardial injury. Though none of the patients seemed to deteriorate clinically from the diazoxide the electrocardiographic changes suggested that the use of intravenous diazoxide to lower blood pressure in patients with acute myocardial infarction might possibly be deleterious.
\end{abstract}

Cardiology Department, Auckland Hospital, Auckland, New Zealand K P O'BRIEN, FRACP, MRCP, senior cardiologist R R GRIGOR, MB, MRACP, cardiology registrar P M TAYLOR, NZRN, sister-in-charge, coronary care unit

\section{Introduction}

Much recent discussion about the treatment of acute myocardial infarction has centred on possible methods for limiting infarct size, and it has been suggested that certain manipulatious carried out after the patient's arrival in hospital might salvage quantities of myocardium.

Because blood pressure is one of the main determinants of myocardial oxygen demand it has been suggested ${ }^{1}$. that a reduction in abnormally raised blood pressure in patients with acute myocardial infarction might reduce infarct size and thus mortality. Shell and Sobel ${ }^{2}$ have reported beneficial results from reducing blood pressure with trimethaphan camsylate, and others ${ }^{3}{ }^{4}$ have shown benefit from the use of vasodilators such as nitroprusside and phentolamine. Cardiac rupture after myocardial infarction ${ }^{5}$ occurs more often in patients who are hypertensive than in those who are normotensive, which also suggests that it might be advantageous to lower abnormally raised blood pressures in patients with acute infarction.

To our knowledge there have been no previous reports on the use of intravenous diazoxide in patients with hypertension associated with acute myocardial infarction. Intravenous diazoxide was considered a suitable agent for use in acute myocardial infarction because of its well-known speed of action and efficacy and also because it has been shown to increase coronary blood flow and cardiac output. ${ }^{6-8}$ Furthermore, the use of intravenous diazoxide has not been associated with the pronounced increase in heart rate that occurs with some other intravenous blood pressure lowering agents such as hydrallazine.

Thus we undertook a trial to assess the effects of intravenous diazoxide in 20 patients with proved recent myocardial infarction and associated hypertension. 


\section{Patients and methods}

Patients selected for study had to have a systolic blood pressure of $180 \mathrm{~mm} \mathrm{Hg}$ or more or diastolic pressure of $110 \mathrm{~mm} \mathrm{Hg}$ or more, or both, that had persisted for one hour after admission to the coronary care unit. Among 289 consecutive admissions to the Auckland Hospital coronary care unit over six months 20 patients $(7 \%)$ met the criteria for inclusion in the study. At the time of admission to the unit the patients were treated in a similar fashion to all other admissions, and oxygen and pain relief were given according to the usual practice in the unit.

The 16 men and four women ranged in age from 37 to 72 years (mean 58 years). The time from onset of symptoms to inclusion in the study ranged from three hours to 36 hours (mean 11.6 hours). Nine patients had anterior myocardial infarctions, three had inferior myocardial infarctions, and eight had subendocardial infarction. Serum enzymes were abnormally raised in all patients. Eight of the 20 patients had a past history of known hypertension and six of these were taking antihypertensive drugs up to the time of admission. Another three patients had been taking beta-adrenergic blocking drugs for angina before admission. Blood urea and serum creatinine were normal in all 20 patients.

At the time of admission an intravenous drip was inserted and patients with residual significant pain were given intravenous papaveretum (Omnopon; $5 \mathrm{mg}$ doses), which was repeated as necessary.

During the first hour of admission and before the start of the study blood pressure had been measured at least three times. Immediately before intravenous diazoxide was given baseline heart rates were recorded on the cardiac monitor, baseline supine blood pressure was recorded with a cuff sphygmomanometer, and a baseline 12-lead electrocardiogram was recorded. A $300-\mathrm{mg}$ bolus of diazoxide was then injected rapidly into the existing intravenous drip. Blood pressure and heart rate were recorded after one minute, then every five minutes for the first hour, and subsequently every two hours for the next 24 hours. After the diazoxide electrocardiograms were recorded after five minutes, 15 minutes, and 60 minutes. A further electrocardiogram was recorded on the day after the study. Coloured markers were placed on the chest wall to ensure that electrode positions were identical during each electrocardiographic recording.

Observations were made on the severity of any chest pain existing before and after each injection of diazoxide and inquiries were made about any side effects of the drug. If the blood pressure returned to $180 / 110 \mathrm{~mm} \mathrm{Hg}$ or more after the first injection then a further 300-mg bolus of diazoxide was given. After completion of the study the patients were kept in the coronary care unit, where they underwent routine treatment and observation.

\section{Results}

The results of the study are summarised in the table. Thirteen patients required only one $300-\mathrm{mg}$ bolus of diazoxide to reduce blood pressure to less than $180 / 110 \mathrm{~mm} \mathrm{Hg}$ but seven patients required two injections. The second 300-mg bolus of diazoxide was given 14 to 120 minutes (mean 60 minutes) after the first. The average blood pressure before the diazoxide was $194 / 122 \mathrm{~mm} \mathrm{Hg}$ and the highest blood pressure at the start of the study was $230 / 160 \mathrm{~mm} \mathrm{Hg}$. Blood pressure fell after each diazoxide injection by 20 to $110 \mathrm{~mm} \mathrm{Hg}$ systolic and 15 to 70 $\mathrm{mm} \mathrm{Hg}$ diastolic. The average fall was $58 / 40 \mathrm{~mm} \mathrm{Hg}$. No patient became severely hypotensive, and the lowest pressures recorded were $90 \mathrm{~mm} \mathrm{Hg}$ systolic and $60 \mathrm{~mm} \mathrm{Hg}$ diastolic. The arterial systolic pressure fell to $100 \mathrm{~mm} \mathrm{Hg}$ or below in only two patients. The maximum fall in blood pressure occurred within five minutes of injection on 20 occasions and within the first minute on 12 of these.

The fall in blood pressure lasted from five minutes to over 24 hours (see table). The duration of the fall was less in the eight patients with a history of hypertension, and blood pressure remained normal in only two of these over the first 24 hours. The blood pressure remained normal for 24 hours or more in 11 of the other 12 patients. There was no significant difference in the degree of fall of the blood pressure between those with a history of hypertension and those without. The average heart rate increased by 10 beats $/ \mathrm{min}$, and the increase in heart rate was greater than 10 beats/min in 16 patients. The maximum increase was 33 beats/min.

In most patients there was no change in any existing chest pain as a result of the diazoxide injection. One patient (case 2 ) noticed a definite sudden decrease in his chest pain after the diazoxide injection and one other patient (case 3 ) noted a sudden increase in the severity of chest pain. The heart rate did not change substantially in either of these patients. Apart from mild discomfort at the site of the intravenous injection no significant side effects of diazoxide were noted.

Electrocardiographic changes suggestive of increased myocardial ischaemia appeared in nine patients within minutes of the diazoxide injection. In eight of these nine patients electrocardiographic changes were those of S-T segment and T-wave alterations (figs 1 and 3 ). One patient (fig 2) developed right bundle-branch block within 15 minutes of the diazoxide injection.

The clinical course of these 20 patients did not seem to be significantly altered by the diazoxide injection and no lasting obvious clinical deterioration was noted. One patient (case 17) died in hospital seven days after admission, but the remaining 19 patients were discharged from hospital.

\section{Discussion}

Arterial pressure is often raised during the early phase of acute myocardial infarction. This increase may be a result of pre-existing hypertension or catecholamine release. ${ }^{9}$ Whatever the cause of increased blood pressure in this condition, however, it is generally believed that the increase is harmful, and Shell

Blood pressures, heart rate, and electrocardiographic (ECG) changes after intravenous diazoxide

\begin{tabular}{|c|c|c|c|c|c|c|c|c|}
\hline \multirow{2}{*}{$\begin{array}{l}\text { Case } \\
\text { No }\end{array}$} & \multirow{2}{*}{$\begin{array}{c}\text { Age } \\
\text { (years) }\end{array}$} & \multicolumn{2}{|c|}{ Blood pressure $(\mathrm{mm} \mathrm{Hg})$} & \multirow{2}{*}{$\begin{array}{l}\text { Time from } \\
\text { diazoxide to } \\
\text { peak fall } \\
(\mathrm{min})\end{array}$} & \multirow{2}{*}{$\begin{array}{l}\text { Duration of } \\
\text { fall }\end{array}$} & \multicolumn{2}{|c|}{ Heart rate/min } & \multirow{2}{*}{$\begin{array}{l}\text { ECG changes } \\
\text { after diazoxide }\end{array}$} \\
\hline & & $\begin{array}{c}\text { Before } \\
\text { diazoxide }\end{array}$ & $\begin{array}{l}\text { Maximum } \\
\text { fall }\end{array}$ & & & $\begin{array}{c}\text { Before } \\
\text { diazoxide }\end{array}$ & $\begin{array}{c}\text { After } \\
\text { diazoxide }\end{array}$ & \\
\hline 1 & 51 & $180 / 120$ & $55 ! 50$ & 5 & $8 \mathrm{~h}$ & 115 & 105 & $\begin{array}{l}\text { 2-mm S-T elevation inferior } \\
\text { leads, } \mathrm{S}-\mathrm{T} \text { depression V2-V3 }\end{array}$ \\
\hline 2 & 47\{ & $\begin{array}{l}210 / 140 \\
170 / 110\end{array}$ & $\begin{array}{l}85 / 60 \\
20 / 20\end{array}$ & $\begin{array}{l}1 \\
1\end{array}$ & $\begin{array}{r}5 \mathrm{~min} \\
30 \mathrm{~min}\end{array}$ & $\begin{array}{l}100 \\
100\end{array}$ & $\begin{array}{l}100 \\
105\end{array}$ & $\begin{array}{l}\text { No change } \\
\text { No change }\end{array}$ \\
\hline 3 & 72 & $200 / 130$ & $95 / 60$ & 15 & $>24 \mathrm{~h}$ & 85 & 90 & Marked $S-T$ and $T$ changes \\
\hline 4 & 48\{ & $\begin{array}{l}190 / 140 \\
190 / 120\end{array}$ & $\begin{array}{l}40 / 40 \\
30 / 20\end{array}$ & $\begin{array}{l}1 \\
1\end{array}$ & $\begin{array}{l}40 \mathrm{~min} \\
>24 \mathrm{~h}\end{array}$ & $\begin{array}{r}90 \\
110\end{array}$ & $\begin{array}{l}100 \\
110\end{array}$ & $\begin{array}{l}\text { No change } \\
\text { No change }\end{array}$ \\
\hline 5 & 60 & $180 / 130$ & $60 / 70$ & 30 & $>24 \mathrm{~h}$ & 105 & 75 & No change \\
\hline 6 & 61\{ & $\begin{array}{l}220 / 110 \\
200 / 100\end{array}$ & $\begin{array}{l}40 / 25 \\
30 / 20\end{array}$ & $\begin{array}{l}5 \\
5\end{array}$ & $20 \mathrm{~min}$ & $\begin{array}{l}50 \\
62\end{array}$ & $\begin{array}{l}65 \\
80\end{array}$ & $\begin{array}{l}\text { No change } \\
\text { No change }\end{array}$ \\
\hline 7 & 63 & $185 / 90$ & $75 / 25$ & 5 & $>24 \mathrm{~h}$ & 47 & 65 & No change \\
\hline $\begin{array}{r}8 \\
9 \\
10\end{array}$ & $\begin{array}{l}37 \\
62\end{array}$ & $\begin{array}{l}200 / 105 \\
180 / 115 \\
180 / 120\end{array}$ & $\begin{array}{r}110 / 30 \\
30 / 20 \\
70 / 40\end{array}$ & $\begin{array}{r}60 \\
1 \\
1\end{array}$ & $\begin{array}{l}>24 \mathrm{~h} \\
45 \mathrm{~min} \\
>24 \mathrm{~h}\end{array}$ & $\begin{array}{l}70 \\
80 \\
68\end{array}$ & $\begin{array}{l}80 \\
90 \\
60\end{array}$ & $\begin{array}{l}\text { T-inversion lateral chest leads } \\
\text { No change } \\
\text { Increased } S-T \text { depression }\end{array}$ \\
\hline 11 & 57\{ & $\begin{array}{l}230 / 160 \\
210 / 150\end{array}$ & $\begin{array}{l}30 / 40 \\
20 / 40\end{array}$ & $\begin{array}{l}1 \\
1\end{array}$ & $\begin{array}{l}10 \mathrm{~min} \\
20 \mathrm{~min}\end{array}$ & $\begin{array}{l}00 \\
118 \\
128\end{array}$ & $\begin{array}{l}130 \\
130\end{array}$ & $\begin{array}{l}\text { Inverted T-waves in anterior } \\
\text { chest leads became upright }\end{array}$ \\
\hline 12 & $59\}$ & $\begin{array}{l}180 / 120 \\
175 / 130\end{array}$ & $\begin{array}{l}25 / 20 \\
25 / 25\end{array}$ & 5 & $10 \mathrm{~min}$ & 110 & $\begin{array}{l}125 \\
130\end{array}$ & $\begin{array}{l}\text { No change } \\
\text { No change }\end{array}$ \\
\hline 13 & & $190 / 115$ & $\begin{array}{l}25 / 25 \\
20 / 20\end{array}$ & $\begin{array}{l}1 \\
1\end{array}$ & $20 \mathrm{~min}$ & $\begin{array}{r}125 \\
85\end{array}$ & $\begin{array}{l}130 \\
112\end{array}$ & Minor T-wave changes \\
\hline $\begin{array}{l}13 \\
14\end{array}$ & $\begin{array}{l}48 \\
68\end{array}$ & $\begin{array}{l}190 / 115 \\
170 / 115\end{array}$ & $\begin{array}{l}20 / 15 \\
80 / 55\end{array}$ & $\begin{array}{r}1 \\
10\end{array}$ & $\begin{aligned} & 25 \mathrm{~min} \\
> & 24 \mathrm{~h}\end{aligned}$ & $\begin{array}{r}85 \\
100\end{array}$ & $\begin{array}{l}118 \\
100\end{array}$ & $\begin{array}{l}\text { anterior chest leads } \\
\text { Right bundle-branch block }\end{array}$ \\
\hline 15 & 48 & $220 / 140$ & $60 / 50$ & 20 & $>24 h$ & 100 & 130 & $\begin{array}{l}\text { developed } \\
\text { Increase in } S-T \text { elevation }\end{array}$ \\
\hline 16 & 69 & $180 / 120$ & $70 / 40$ & 1 & $>24 \mathrm{~h}$ & 72 & 75 & $\begin{array}{l}\text { anterior chest leads } \\
\text { Marked } S-T \text { and } T \text {-wave }\end{array}$ \\
\hline 17 & 55 & $\begin{array}{l}210 / 100 \\
190 / 100\end{array}$ & $\begin{array}{l}40 / 20 \\
30 / 20\end{array}$ & 10 & $25 \mathrm{~min}$ & $\begin{array}{r}64 \\
100\end{array}$ & $\begin{array}{r}96 \\
115\end{array}$ & $\begin{array}{l}\text { No change } \\
\text { No change }\end{array}$ \\
\hline $\begin{array}{l}18 \\
19 \\
20\end{array}$ & $\begin{array}{l}62 \\
62 \\
54\end{array}$ & $\begin{array}{l}190 / 120 \\
220 / 140 \\
160 / 120\end{array}$ & $\begin{array}{l}50 / 30 \\
80 / 50 \\
50 / 40\end{array}$ & $\begin{array}{r}20 \\
5 \\
5 \\
5\end{array}$ & $\begin{array}{l}>24 \mathrm{~h} \\
>24 \mathrm{~h} \\
>24 \mathrm{~h}\end{array}$ & $\begin{array}{r}100 \\
75 \\
60 \\
78\end{array}$ & $\begin{array}{r}98 \\
70 \\
100\end{array}$ & $\begin{array}{l}\text { No change } \\
\text { No change } \\
\text { No change }\end{array}$ \\
\hline
\end{tabular}





FIG 1-Case 3. Electrocardiogram (a) immediately before diazoxide (blood pressure $200 / 130 \mathrm{~mm} \mathrm{Hg}$ ), (b) 5 minutes after diazoxide $(110 / 70 \mathrm{~mm} \mathrm{Hg}$ ), and $(c) 1$ hour after diazoxide $(110 / 70 \mathrm{~mm} \mathrm{Hg}) . \mathrm{S}-\mathrm{T}$ and $\mathrm{T}$-wave changes in V3-V5 are suggestive of increased myocardial injury after diazoxide.

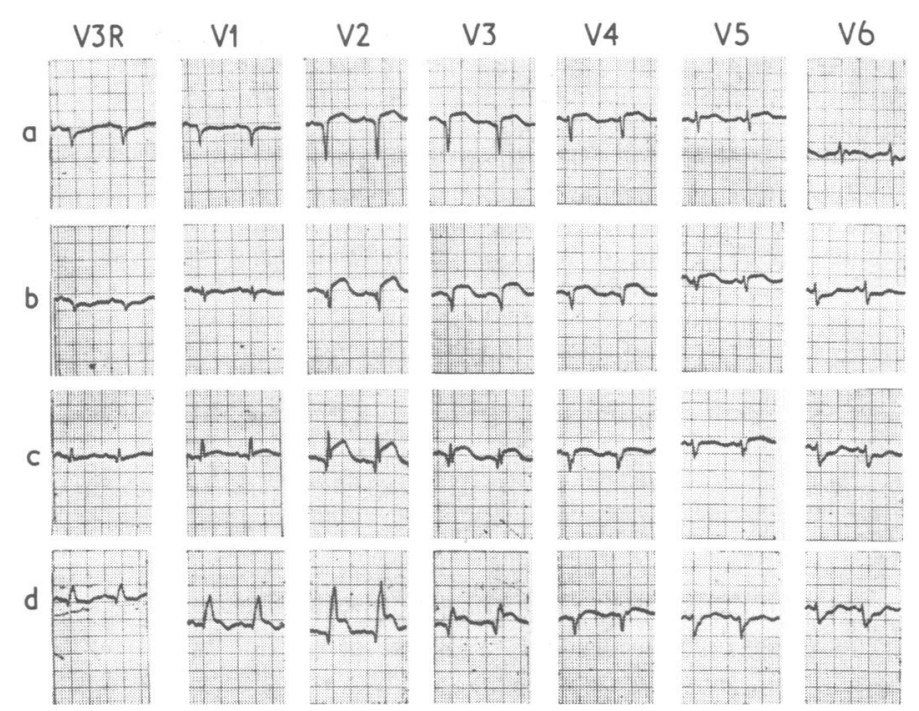

FIG 2-Case 14. Electrocardiogram (a) immediately before (blood pressure $175 / 115 \mathrm{~mm} \mathrm{Hg}),(b) 10$ minutes after $(90 / 60 \mathrm{~mm} \mathrm{Hg}),(c) 20$ minutes after $(100 / 70 \mathrm{~mm} \mathrm{Hg})$, and $(d) 30$ minutes after $(100 / 70 \mathrm{~mm} \mathrm{Hg})$ diazoxide. V1 and V2 show development of right bundle-branch block and S-T changes after diazoxide.
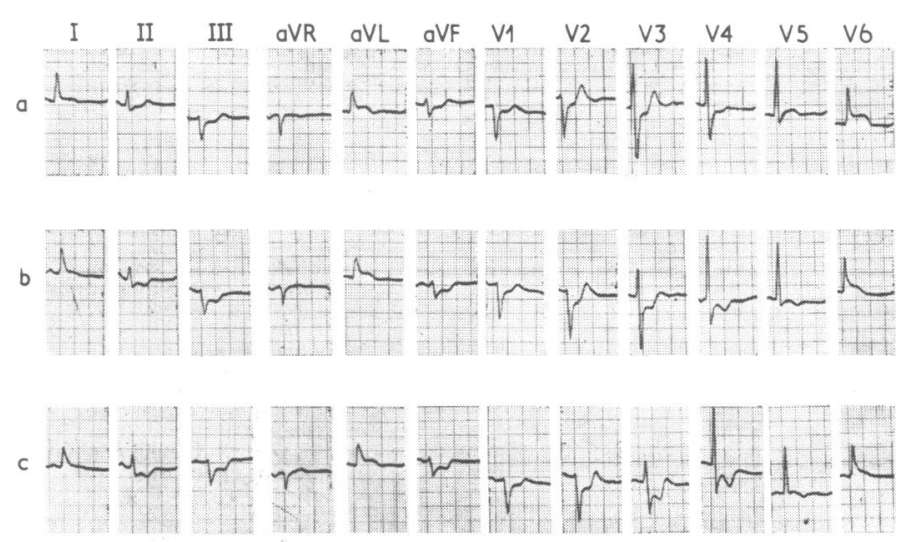

FIG 3-Case 16. Electrocardiogram (a) immediately before (blood pressure $180 / 120 \mathrm{~mm} \mathrm{Hg}),(b) 5$ minutes after $(140 / 100 \mathrm{~mm} \mathrm{Hg})$, and $(c) 15$ minutes after $(150 / 110 \mathrm{~mm} \mathrm{Hg})$ diazoxide. Increased S-T depression in leads II, III, V3, and V4 after diazoxide suggests increase in myocardial ischaemia. and Sobel ${ }^{2}$ have recently suggested that infarct size is likely to be increased by the persistence of untreated hypertension.

Clearly, if abnormal blood pressure associated with myocardial infarction is thought to be deleterious then significant blood pressure lowering should be achieved within a short time of admission. In these circumstances routine treatment with antihypertensives such as methyldopa, guanethidine, betablockers, diuretics, and other well-established agents is unlikely to be rapid enough. Intravenous hydrallazine would not be suitable because it increases the heart rate. The results obtained in our 20 patients show that intravenous diazoxide acts quickly to lower raised blood pressure associated with acute myocardial infarction. In most of the patients the resultant blood pressure levels were acceptable, and severe hypotension did not occur.

Nine patients showed electrocardiographic changes immediately after the intravenous diazoxide that suggested an increase in myocardial injury. These "deleterious" electrocardiographic changes tended to be associated with the greater falls in blood pressure; the average fall among the nine patients was $66 / 43 \mathrm{~mm} \mathrm{Hg}$, whereas that in the patients without adverse electrocardiographic changes averaged $52 / 36 \mathrm{~mm} \mathrm{Hg}$. Nevertheless, deleterious electrocardiographic changes did occur in some patients who did not show a steep fall in blood pressure. In contrast to the finding that the electrocardiographic changes in nine patients suggested increased myocardial injury, none of the other patients showed electrocardiographic changes suggestive of decreased myocardial injury.

The time from the onset of symptoms to the diazoxide treatment in the nine patients with deleterious electrocardiographic changes ranged from four to 12 hours (mean eight hours). In the other 11 patients the time from the onset of symptoms to the diazoxide treatment ranged from four to 23 hours (mean 13 hours). Although some time difference existed between the two groups, it seems unlikely that the apparently deleterious changes were due to the time difference in view of the fact that the electrocardiographic changes occurred almost immediately after the administration of the drug.

The presumed deleterious effects in these nine patients could not readily be attributed to important changes in heart rate, as the increase in heart rate in these nine patients ranged from -10 to +30 beats/min (mean +8 ). Haemodynamic measurements were not made in this study, and other studies ${ }^{3}{ }^{4}$ in which haemodynamic measurements were made have suggested haemodynamic improvement after treatment with vasodilators and blood pressure lowering agents. Perhaps more significantly, Shell and Sobel ${ }^{2}$ found evidence of reduced infarction size by using enzyme decay curves and predicted creatinine phosphokinase values. None of these studies, however, reported any electrocardiographic changes that occurred after vasodilator or blood pressure lowering treatment.

Although it is generally considered that raised blood pressure in the presence of acute myocardial infarction is disadvantageous some experimental evidence does not necessarily support this view. Maroko et al ${ }^{10}$ made observations in dogs that suggested that the changes in coronary flow as a result of lower arterial perfusion pressure might be more important than the reduction in myocardial oxygen consumption as a result of blood pressure lowering. Maroko et al found that in contrast to the influence of positive inotropic agents, an increase of arterial blood pressure that also augmented myocardial consumption nevertheless decreased the extent of ischaemic injury. Conversely, arterial hypotension that reduced myocardial oxygen needs had the effect of extending ischaemic injury. These animal studies suggested that an increase in blood pressure proportionally increased coronary blood flow more than myocardial oxygen requirements.

Possibly the dose of intravenous diazoxide we used was excessive. Nevertheless, severe hypotension did not occur in any patient, and that the blood pressure obtained after the $300-\mathrm{mg}$ injection was within the limits usually accepted clinically as being satisfactory for patients with acute myocardial infarction. Coronary blood flow is largely dependent on aortic diastolic pressure, and the diastolic pressure in this study fell below $80 \mathrm{~mm} \mathrm{Hg}$ 
in six of the patients, and $60 \mathrm{~mm} \mathrm{Hg}$ was the lowest diastolic pressure recorded. It is also possible that the fall in blood pressure caused by this dose of diazoxide occurred too rapidly, and a further approach might be to lower pressure more gradually by smaller repeated doses.

Despite the theoretical advantages associated with the use of intravenous diazoxide in the treatment of hypertension associated with acute myocardial infarction, the observed electrocardiographic changes in nine of the 20 patients in this study lead us to recommend caution in the use of diazoxide. More detailed studies on haemodynamic changes and detailed enzyme studies might be helpful in confirming or refuting the results suggested by this study.

\section{References}

1 British Medical fournal, 1975, 1, 353.

2 Shell, W E, and Sobel, B E, New England fournal of Medicine, 1974, 291, 481.

${ }^{3}$ Franciosa, J A, et al, Lancet, 1972, 1, 650.

${ }^{4} \mathrm{Kelly}, \mathrm{D}$ T, et al, Circulation, 1973, 47, 729.

${ }^{5}$ Naeim, F, de la Maza, L M, and Robbins, S L, Circulation, 1972, 45, 1231.

6 Nayler, W G, et al, American Heart fournal, 1968, 75, 223.

${ }^{7}$ Rowe, G G, et al, American Heart fournal, 1963, 66, 636.

${ }^{8}$ Scott, J C, and Cowley, A W, American fournal of Cardiology, 1969, 24, 865.

9 Siggers, D C, Salter, C, and Fluck, D C, British Heart fournal, 1971, 33 , 878.

${ }^{10}$ Maroko, P R, et al, Circulation, 1971, 43, 67.

\title{
Trigger factors and HL-A antigens in chronic active hepatitis
}

\author{
JOHAN LINDBERG， ANNIKA LINDHOLM， PER LUNDIN， STEN IWARSON
}

British Medical fournal, 1975, 4, 77-79

\section{Summary}

Forty-six patients with histologically verified chronic active hepatitis (CAH) were divided into three groups according to whether the CAH was virus-induced, druginduced, or cryptogenic. The frequency of the HL-A antigens 1 and 8 was increased in the cryptogenic group while the other groups did not differ significantly from healthy controls. Autoantibodies were often found in high titres in the drug-induced and cryptogenic groups but were infrequent in the virus-induced group.

\section{Introduction}

The aetiology and pathogenesis of chronic active hepatitis (CAH) have been discussed since the disease was first described by Waldenström in $1950 . .^{1}$ Most cases are still considered to be of unknown origin but some are apparently secondary to viral hepatitis or to prolonged use of oxyphenisatin. Autoimmune phenomena such as hypergammaglobulinaemia and tissue antibodies are present to a variable degree, and autoimmune mechanisms are probably involved irrespective of the triggering factor. Recent studies on HL-A antigens in CAH have suggested that genetic factors are associated with this type of abnormal immunoreactivity. ${ }^{2}$

Several cases of $\mathrm{CAH}$ present without demonstrable trigger factors and causes other than hepatitis viruses and oxyphenisatin should be searched for. We attempted to divide 46 patients with $\mathrm{CAH}$ according to possible trigger factors and correlate the distribution of HL-A antigens to such factors.

Östra Sjukhuset (University of Gothenburg), S-416 85 Gothenburg, Sweden

JOHAN LINDBERG, MD, assistant physician, department of infectious diseases

STEN IWARSON, MD, associate professor, department of infectious diseases

PER LUNDIN, MD, professor, department of pathology I

Blood Centre, Sahlgrenska Sjukhuset, Gothenburg, Sweden

ANNIKA LINDHOLM, MD, assistant head physician

\section{Patients and methods}

During 1967-73 65 patients with histologically verified CAH were seen and examined at the clinic for infectious diseases in Gothenburg. Forty-six of these patients, who were seen during their first attack of jaundice in what turned out to be a chronic liver disease, were studied. All patients were examined before any treatment was started. No addict of alcohol or drugs was included and all patients were native Swedes. They were 14-84 years old (mean 52 years) and included 33 women $(72 \%)$.

Serial liver biopsy specimens were obtained by a transthoracic route according to a modified Menghini technique. The histological analyses were made according to principles given by international groups. ${ }^{3}{ }^{4}$ Hepatitis B surface antigen ( HBsAg) was shown in serum by immunodiffusion, immunoelectro-osmophoresis, and radioimmunoassay, as has been described in detail. ${ }^{5}$ Biochemical liver function tests were performed using standard techniques. ${ }^{5}$ The analyses of antinuclear antibodies (ANA), smooth muscle antibodies (SMA), and antimitochondrial antibodies (AMA) were performed by immunofluorescence at the State Bacteriological Laboratory, Stockholm, Sweden.

HL-A antigens were determined by the lymphocytotoxicity microtechnique. ${ }^{6}$ The lymphocyte suspension was prepared according to the technique originally described by Böyum and modified by Thorsby et al. ${ }^{7}$ The frequency of the HL-A antigens in the patients was compared with the frequency in a control group of 690 unrelated healthy Swedes.

\section{Results}

POSSIBLE TRIGGER FACTORS

Virus-induced $C A H$-In 15 patients $(33 \%)$, ranging in age from 27-70 years (mean 53), the initial attack of jaundice was diagnosed as viral hepatitis. Nine of the group were men. Ten of these patients had histological signs of classic viral hepatitis and three also had demonstrable serum HBsAg. In the remaining five patients liver biopsy was not performed during the initial attack of jaundice but the presence of serum HBsAg suggested hepatitis B infection. In three of the eight antigen-positive cases $\mathrm{HBsAg}$ was only transiently demonstrable. These 15 patients were among about 1600 patients with hepatitis admitted to the hospital during the period of study. The interval from the acute attack of viral hepatitis to the first histological signs of CAH ranged from one to five years (mean 1.5). Follow-up liver biopsies because the disease became clinically chronic showed development of chronic aggressive hepatitis histologically in all 15 patients primarily diagnosed as having viral hepatitis.

Drug-induced $C A H-$ Thirteen patients $(28 \%)$, aged 27-75 years (mean 55) and including three men, presented with a histological picture of CAH at their first attack of jaundice and had a history of drug treatment in association with onset of symptoms. The drugs, 